\title{
Boundary conditions for the implementation of smart management systems in tourist destinations
}

\author{
Magdalena Kachniewska
}

\begin{tabular}{|c|c|}
\hline \multicolumn{2}{|r|}{ A B STR ACT } \\
\hline \multicolumn{2}{|c|}{$\begin{array}{l}\text { Objective: Purpose of this paper is twofold: (1) to indicate the business and technolog } \\
\text { ical foundations of smart tourism, as well as prospects for its further development; ( } 2 \\
\text { to indicate factors and barriers to the development of smart tourism management sys } \\
\text { tem in Poland. The paper then discusses a series of challenges currently neglected ir } \\
\text { the practical smart tourism agendas and the academic literature. }\end{array}$} \\
\hline \multicolumn{2}{|c|}{$\begin{array}{l}\text { Research Design \& Methods: A combination of } 3 \text { methods was used: mind mapping, } \\
\text { STEEP analysis and semi-structured interview with } 48 \text { experts, representing tourism in- } \\
\text { dustry new-tech sector. All the interviewees were interviewed in Jan/Feb } 2020 \text {. }\end{array}$} \\
\hline \multicolumn{2}{|c|}{$\begin{array}{l}\text { Findings: The article presents the general concept of the smart tourism and smart tour- } \\
\text { ism destination (STD) development and identifies opportunities and threads to the de- } \\
\text { velopment of smart tourism in Poland. }\end{array}$} \\
\hline \multicolumn{2}{|c|}{$\begin{array}{l}\text { Contribution \& Value Added: The article is an important value from the point of view } \\
\text { of tourism industry practitioners (destination managers). The study contributes with } \\
\text { valuable insights on how the chances of implementing smart tourism assumptions are } \\
\text { perceived in Poland. The final diagram gives the idea of big data availability and usabil- } \\
\text { ity in tourism and its impact on management efficiency. }\end{array}$} \\
\hline Article type: & \\
\hline Keywords: & \\
\hline & \\
\hline & \\
\hline
\end{tabular}

\section{Suggested citation:}

Kachniewska, M. (2020). Boundary conditions for the implementation of smart management systems in tourist destinations. International Entrepreneurship Review (previously published as International Entrepreneurship / Przedsiębiorczość Międzynarodowa), 6(4), 35-50. https://doi.org/10.15678/IER.2020.0604.03

\section{INTRODUCTION}

The concept of "Territorial Intelligence" (smart city, smart region) has emerged, based on three-element dynamics including: sustainable development; network-based management 
and the use of intelligent technologies to collect, process and diffuse information. The aim of the article is: (1) to connect the concept of territorial intelligence and tourism; (2) to analyse the state of research on smart tourist regions; (3) to present the results of a semistructured expert interview, conducted to understand business and technological foundations of smart tourism destination in Poland.

The first part reviews current scientific research and brings to the concept of smart tourism destination (hereinafter called STD), as well as the components of implementation of solutions that make up the smart tourism system. In the second part, the review of the literature was used to discuss the most advanced and promising technological achievements and the possible framework of their application in tourism. The third and fourth parts present the methodology and results of the empirical research carried out with the participation of Polish tourism market experts. They presented not only their own opinions on the concept of STD and prospects for the implementation of technological solutions in tourism practice, but also the basic requirements for integration and standardization for the efficient use of these technologies (see the final diagram).

\section{LITERATURE REVIEW AND THEORY DEVELOPMENT}

\section{The concept of smart tourism destination (STD)}

The analogy between the goals of the development of the city and the tourism destination as well as the possibility of achieving these goals with the support of modern technologies, obviously arises. Komninos (2008) believes that a smart city/commune/cluster/region is an area consisting of four main elements:

- creative population carrying out intensive use of knowledge,

- effective institutions and procedures for creating knowledge that enable it to be acquired and adapted,

- developed broadband infrastructure, digital spaces, e-services and online tools for knowledge management,

- documented ability to innovate, manage and solve problems that appear for the first time, as innovation and management are crucial to assess intelligence under uncertainty.

The terms 'intelligent tourism' and 'intelligent tourist destination' are already commonly used in literature (Baggio\& Del Chiappa, 2014; Gretzel et al., 2015). A number of researchers undertake to formulate the technological foundations of this concept and analyze case studies of cities/regions (Femenia-Serra \& Perea-Medina, 2016; GonzálezReverté, 2019) that more or less correspond to the concept of intelligent destination. Numerous studies have been undertaken on STD assessment framework (Baggio \& Del Chiappa, 2014; Femenia-Serra \& Perea-Medina, 2016; Gretzel et al., 2015; Vasavada \& Padhiyar, 2016; Masseno \& Santos, 2018). The concept of a STD refers to the development of ICT infrastructure, which is flexible and service-oriented as its purpose is to meet the needs of all stakeholders: local authorities, entrepreneurs, tourists and residents. The data stream is no longer merely an illustration of real processes, but through intelligent technologies it has a real impact on the operation of the entire system. As long as these two spheres (online and offline) do not begin to permeate, there will be no structurally strong, uniform, evolutionary system of the intelligent region (Baggio \& DelChiappa, 2014; Gretzel et al. 2015). 
STDcould be defined as "tourism supported by integrated efforts at a destination, to find innovative ways to collect and aggregate data derived from physical infrastructure, social connections, organizational sources and human bodies/minds in combination with the use of advanced technologies to transform that data into enhanced experiences and business value-propositions with a clear focus on efficiency, sustainability and enriched experiences during the trip" (Gretzel et al., 2015, p. 180) or "an innovative tourist destination, built on an infrastructure of state-of-the-art technology guaranteeing the sustainable development of tourist areas, accessible to everyone, which facilitates the visitor's interaction with and integration into his or her surroundings, increases the quality of the experience at the destination, and improves residents' quality of life" (Lopez de Avila, 2015, p. 27). STDs are characterized by the ability to transform large amounts of data into enhanced tourist experiences and increased destination competitiveness thanks to the interconnection of the different stakeholders through latest ICT advancements, which allow a better decision-making (Femenia-Serra \& Perea-Medina, 2016).

\section{The sources and benefits of using big data in tourism}

The information intensive nature of tourism make it an ideal match for use of ICT (Kachniewska, 2014; Olsen\& Connolly, 2000). The amount of underdeveloped tourist data results from the frequency of online transactions, a large number of Internet searches, the use of price comparators and social networks. The data is irrelevant when it is isolated from the context - it becomes the basis for management decisions when it is analyzed together with the entire data set (Frederiksen, 2012; Hendrik \& Perdana, 2014;Manyika et al., 2011).

Records of credit card transactions, search engine traffic statistics, and user-generated content (UGC) on social media can reveal trends and complex patterns and provide useful patterns of tourists' behavior and desires, enable forecasting of certain phenomena, provide the basis for business decisions, and more effective forecasting (Mariani et al., 2018). Many studies have used structured search-engine data for tourism now casting and forecasting (Artola et al., 2015; Jeng \& Fesenmaier, 2002: Yang et al., 2015).Particularly high hopes are associated with the development of wearable devices and the Internet of Things (IoT), which is already heavily used in the field of tourism industry: e.g.to personalize various settings of the environment (temperature, lighting, water flows, etc.) in hotels, to access control or verification of the operational status of individual elements, to optimize repairs and maintenance).In tourist destinations, loT helps to monitor visitor flows, enables traffic management in the city or region, provides personalized information about the location and available transport connections, attractions, shopping (on the basis of mobile applications and e-guides, or based on beacons) (Guttentag, 2010; Kurilovas, 2016). Cellphone roaming data and Bluetooth tracking data can also help understand the pattern of tourist flows at different scales. A group of researchers from Estonia utilized a nationwide roaming mobile dataset of the Estonian GSM network to study the spatial-temporal pattern of inbound tourists (Ahas et al., 2008). Bluetooth tracking technology enables to understand tourists' spatial-temporal movement patterns (Versichele et al., 2012).

The availability of information allows taking action to counteract the negative aspects of concentration of tourist traffic (relocation of tourist streams to less burdened places), which in turn brings both improvement of economic efficiency and better feelings of tourists. The advantage of this type of solution over the traditional tourist information system (maps, folders, labeling of facilities) lies mainly in the fact that they can 
stimulate tourist decisions ("push" messages displayed on the monitor of a mobile device) (Cooper \& Macneil, 2005; Kachniewska, 2014). This is especially valuable in those places where no forms of personal support are available (e.g. remote areas, tourist routes), but also in facilities where the scale of tourist traffic exceeds the possibilities of personal contact between staff and visitors (huge events).

Wearable devices move us towards the data-driven "sensor society" where an individual leaves a huge data footprint during the course of his/her everyday life, which creates opportunities for business development (Swan, 2013). Some of these devices can exchange stored information via wireless, NFC, and iBeacon technology. They enable to track physical behaviors from the external information provided by tourists and to guess quite accurately the emotional state of tourists at a specific moment (Swan, 2013).Song and Liu (2017) introduced a framework that incorporates big data produced by tourists themselves that increases knowledge of the target market into tourism demand forecasting.

Main advantages of tourism big data over traditional methodologies include:

1. Reliability: big data are based on users' real actions, not on surveys (Meeker \& Hong, 2014).

2. New information flows: information is produced by tourists themselves; it enriches the knowledge of tourism businesses' target market and is very useful for analyzing the consumers' demand for different tourism products and services (Hendrik \& Perdana, 2014).

3. Real-time data and now casting: i.e. the use of real-time data to describe contemporaneous activities before official data sources are made available (Bollier\& Firestone, 2010).

Altogether they are quite useful when designing tourism experience and promoting the destination.

\section{Data-based tourism experience}

From a visitor perspective, the availability of mobile tools equipped with the big data solutions and the provision of new personalized information can enrich a tourism experience. An important factor is the strength of the relationship between the message and the context of the tourist's activities at a given time (time of day, location, activity, company of other people, etc.). The system could use the location(extracted from GPS receivers, or through Wi-Fi, cell-id, RFID, etc.), time of day, current weather conditions and forecast, user profile information (in some case extracted from social networks), user constraints and preferences, attractions already visited, location and opening hours of tourists attractions, collaborative user-generated content (e.g., comments, attractions ranking, photographs/videos (Gavalas \& Kenteris, 2011). A tourist might be assisted with attractions, routes and tours recommendations, tourism services and personalized multiple-days tour planning.

Monitoring and understanding of the spatial-temporal pattern of tourist movement provides crucial insights for destination planning and capacity management (Shoval et al., 2013). With the development of reliable and accessible smartphones with built-in GPS, tourists are able to share their user generated contents (UGC) with geo-referenced data (Hawelka et al., 2014) and geo-tagged photos (Hawelka et al., 2014; Shovalet al., 2007; Vu et al., 2015) or to monitor travel routes of tourists (Ahas et al., 2008). Li and Yang (2020) used the geo-tagged Sina Weibo data to understand the nation-wide Chinese domestic tourist movement patterns during the National Day Golden Week in 2014. Several studies have demonstrated how to use big data sources to explore tourists' experience, predict tourist demand, and understand expenditure patterns. 
Ka'da'r (2014) highlighted tourist hotspots in Vienna, Prague and Budapest using geotagged photos and found a high level of correlation between this data and tourism statistics. Vu et al. (2015) introduced a Markov chain model for travel pattern mining on the geo-tagged photos in Hong Kong, and highlighted the travel behavior difference between Asian and Western tourists. Big data analysts capture information of consumer interests from photos posted on social networks: e.g., a tourism provider could push information about local biking routes when they obtain a picture of a mountain bike (Song \& Liu, 2017). Girardin et al. (2008) applied analytical tools to disclose tourist travel routes based on georeferenced photos during their travel. Social media coverage is proven to impact destination image and to influence international tourism flows (Scharl et al., 2020).

According to Govers et al. (2007), tourists' cultivated images are considered as the first of the travel decision-making process. Predictive analytics can relate to weather phenomena, natural disasters and technical problems (e.g. in aviation) - near-field communication (NFC) allow quick contact with travelers and rapid distribution of information (warnings and evacuation tips).Modern tourists like to change the route during travel and combine different travel aims, such as business, vacation, entertainment and education (Kachniewska, 2014). The changing surrounding environments may cause changes in decision-making and behavior (Lamsfus et al., 2014). Travelers often re-negotiate specific details of a trip when a flight is delayed; due to physical fatigue etc. Changes in context and subsequent behavior can transform the way travelers interact and/or experience the destination (Kim \& Fesenmaier, 2015). For tourists themselves, an updated information can be critical in some specific situations: while navigating the destination, looking for specific information or planning their activities.

Profiling customers with big data assistance is beneficial as it provides better services. However, it also possesses a significant thread to users' privacy (Masseno \& Santos, 2018). Gaining concern over users' privacy; users want control over who has access to their private data and feedback on the use of their data.

\section{RESEARCH APPROACH AND METHODS}

As the aim of this study is to understand business and technological foundations of smart tourism destination and how this complexity affects the outcomes when realizing destinations' ambitions, the combination of three qualitative and interpretative methods was used: mind mapping technique, STEEP analysis and a semi-structured interview with48experts: 26 representatives of tourism industry (11 hotel managers, 2 OTA representatives, 3 incoming travel agents, 7 museum/art gallery managers, 3 employees of tourism information centers), 12 DMOs representatives, 1 NTO representative and 8 ICT experts. All the people were interviewed in February 2020.

The purpose of the STEEP analysis was to identify the external environment factors that are opportunities and threats for smart tourism development in Poland, and to determine the strength of this impact. The criteria covered by the STEEP analysis normally include: (1) socio-cultural factors (values, lifestyle, demographic growth, education, employee qualifications, population income, society's attitude towards a given industry), (2) technological factors (scientific discoveries, patents, technology level in a given industry, impact of new technologies, changes in the organization of production), (3) natural environment (environmental protection, pollution, climate change, renewable energy, recycling), (4) economic factors 
(GDP, inflation rate, unemployment rate, budget deficit, market size, interest rates, taxation, exchange rate currency, trade and payment balance, level of wages) and (5) political factors (regulations regarding economic/tourism activity, attitude of the authorities towards the industry, socio-economic ideology of the government, stability of governments, stability of legal regulations, (re) privatization processes, EU membership). The first step of the analysis process was aimed at identification of factors constituting opportunities or threats to smart tourism development in Poland, while the second one was devoted to the quantitative assessment of the importance of the enumerated STEEP factors.

The scale adopted for the purpose of the analysis (1-5) indicated:

5 - a very encouraging environment;

4 - encouraging environment;

3 - neutral environment;

2 - non encouraging environment;

1 - strongly discouraging environment.

Interviewees were also asked to mention the three most negative impacts (outcomes) or unsustainable features of today's tourism development system in their regions/cities and then, rank them by order of importance from the most influential (1) to the least influential (5). On the last stage of the interview they were asked to suggest (or report) the possible solutions to the addressing the most pressing issues of smart tourism destination development process. The interviewees were asked to consider a social/industry perspective in their responses instead of their personal preferences.

\section{FINDINGS}

The research of the opportunities and threats of implementing smart tourism postulates has shown quite different opinions on the importance of different factors. First, the experts have indicated smart tourism development factors, enumerating two groups. They include business and citizen participation, destination leadership and infrastructure, as internal factors. The external factors cover: the availability of data sources, the idea of databased management and decentralized approach to innovation.

The main stakeholders of a smart tourism destination (STD) include: residents and guests (tourists), local government and destination management organization (DMO), budgetary units, municipal companies, educational units, universities and research centers, business entities. They all should be offered a promotional campaign to build a "front" of interest and support. Destination managers are the main actors in building STD and delivering services to citizens, tourist and local businesses, while urban residents, travelers and enterprises should become the most direct beneficiaries: citizens and tourists benefit from the improved quality of life and better experience, while local enterprises can benefit from creating new profits by leveraging STD infrastructure and reliable municipal services. Indirect stakeholders group include providers of smart technology, infrastructure services and applications' developers.

The most important postulates of the experts concerned the following issues:

1. Residents' (including local businesses) participation in STD decisions.

2. The leadership of the destination management organization or local governor. The success or failure of a smart tourism initiative depends on the pace of implementation 
and diffusion of technological solutions. The inclusion of an IT director into the team responsible for developing a STD (digital solutions, appropriate allocation of expertise, employee education, the standardization and interoperability of systems, data sources development and liquidation of data silos).

3. Data-based management. The development of intelligent infrastructure that allows data generation, acquisition, exchange and real-time analysis.

4. The "data center", automatically fed by different destination stakeholders: destinations managers, hoteliers, restaurants, transport companies, museums and other cultural attractions, entertainment and recreation sector, banks, technology companies, etc., and could be the base for making decisions "on-the-go".

The interviewees identified a comparable number of favorable and unfavorable factors, but clearly assigned a higher weight to threats (Table 1).

On the opportunities side, the interviewees pointed mainly to environmental issues and socio-cultural changes. Lower hopes are associated with economic issues (they perceive them mainly in terms of increased costs at the first stage of implementation), political and - the least - technological factors (see Figures 1 and 2).

Within the political factors, interviewees paid attention to public policies, especially developing of a coherent strategy for green energy systems and smart mobility development on a national scale (indicating priority development directions and European guidelines). The overall assessment of these efforts, both at the local and national level, was very low, which reflects the lack of public confidence in the actual involvement of the Polish government in environmental projects. Meanwhile, the development of STD in Poland should first of all be oriented on the issues of sustainable development, because they (1) determine the quality of life and rest of local residents and tourists, (2) are an important element of tourist experience, (3) limit the field of conflicts between visitors and local residents, which is particularly important in regions threatened with over tourism.

Higher weights were given to threatening factors, including: technological, economic and political factors, which - in general - covered insufficient technological competence, low governance transparency, inefficient public-private partnership in destinations, no incentives for launching commercial enterprises with a large "know-how" contribution, and lack of funding for research in the field of smart tourism (Figures 3 and 4).

The most blocking economic factors covered low businesses awareness and ICT readiness, new market structures malevolence (the dominance of new business models based on the disruptive innovations), lack of funding of smart solutions, and low implementation rate and commercialization of innovative technologies. The main obstacle to implementing future-proof solutions is the lack of sufficient funds and the inability to communicate and cooperate with various institutions. Therefore, the implemented projects usually are not based on a holistic approach.

The most optimistic observations of the interviewees concern social and cultural factors. On the opportunities side, they were given very high importance, while on the threads side they were rated as one of the least blocking the development of STD. However, this does not mean that interviewees are not aware of the growing information and technological overload, the growing privacy concern, uneven ICT literacy across the society, digital gaps (young vs. senior tourists; developed vs. developing countries), as well as diversity of contexts, needs and preferences of visitors and local residents, which 
Table 1. Opportunities and threats to the implementation of STD

\begin{tabular}{|c|c|c|}
\hline Factor & Opportunities & Threats \\
\hline 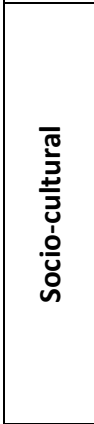 & $\begin{array}{l}\text { - experience economy/tourism trends } \\
\text { - interest in mobility solutions } \\
\text { - improved safety and quality of life } \\
\text { - social interest in smart city solutions } \\
\text { - modern lifestyle } \\
\text { - education level and creativity } \\
\text { - health awareness } \\
\text { - participation in decision-making } \\
\text { - interest in public and social services } \\
\text { - cosmopolitanism/open-mindness } \\
\text { - actual enjoyment assessment }\end{array}$ & $\begin{array}{l}\text { - privacy concerns } \\
\text { - low ICT literacy } \\
\text { - diversity of contexts, needs and prefer- } \\
\text { ences } \\
\text { - lack of public confidence in modern solu- } \\
\text { tions } \\
\text { - psychological effects of smart tourism ex- } \\
\text { periences } \\
\text { - obsolescence and adaptation capacity } \\
\text { - digital gaps: young vs. senior tourists; de- } \\
\text { veloped vs. developing countries }\end{array}$ \\
\hline 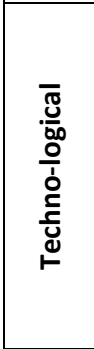 & $\begin{array}{l}\text { - capacity of data } \\
\text { - new technologies development path } \\
\text { - available ICT solutions } \\
\text { - patents, inventions and intellectual prop- } \\
\text { erty protection } \\
\text { - level of digital literacy in society } \\
\text { - growing acceptance and interest in modern } \\
\text { solutions in the field of urban mobility sys- } \\
\text { tems }\end{array}$ & $\begin{array}{l}\text { - dependence on data providers } \\
\text { - property and access to data (governance) } \\
\text { - real value of data } \\
\text { - business opportunism } \\
\text { - SMEs' low ICT literacy } \\
\text { - connectivity limitations } \\
\text { - long Internet response time } \\
\text { - poor technical base }\end{array}$ \\
\hline 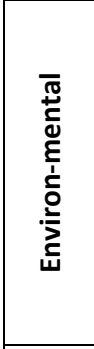 & $\begin{array}{l}\text { - attractivity of natural conditions } \\
\text { - sustainable resource management } \\
\text { - smart systems of tourism flow relocation } \\
\text { - reduction of environmental losses } \\
\text { - lower energy consumption } \\
\text { - reduction of water and air pollution } \\
\text { - reducing the number of vehicles } \\
\text { - technology that does not use harmful sub- } \\
\text { stances }\end{array}$ & $\begin{array}{l}\text { - potential increase in environmental risk by } \\
\text { introducing unknown solutions } \\
\text { - the increase in energy consumption associ- } \\
\text { ated with new needs } \\
\text { - production of harmful waste during the op- } \\
\text { eration of equipment }\end{array}$ \\
\hline  & $\begin{array}{l}\text { - innovative spirit/entrepreneurship } \\
\text { - flexibility of labour market } \\
\text { - international embeddedness } \\
\text { - development of (small and medium) high } \\
\text { technology enterprises } \\
\text { - availability of funds for the development of } \\
\text { environmentally friendly technologies } \\
\text { - growing indicator of implementation and } \\
\text { commercialization of new technologies } \\
\text { - market size }\end{array}$ & $\begin{array}{l}\text { - low businesses awareness and ICT readi- } \\
\text { ness } \\
\text { - new market structures malevolence } \\
\text { - the cost of experts and programmers } \\
\text { - funding of smart solutions } \\
\text { - low implementation rate and commerciali- } \\
\text { zation of innovative technologies } \\
\text { - shortage of qualified staff }\end{array}$ \\
\hline 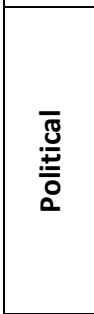 & $\begin{array}{l}\text { - political strategies and perspective } \\
\text { - developing a coherent strategy for the de- } \\
\text { velopment of green energy systems and } \\
\text { smart mobility on a national scale (indicat- } \\
\text { ing priority development directions) and } \\
\text { European guidelines } \\
\text { - increase in development financing } \\
\text { - national scientific and research base }\end{array}$ & $\begin{array}{l}\text { - inefficient public-private partnership in } \\
\text { destinations } \\
\text { - low governance transparency } \\
\text { - no incentives for launching commercial en- } \\
\text { terprises with a large "know-how" contri- } \\
\text { bution } \\
\text { - lack of funding for research }\end{array}$ \\
\hline
\end{tabular}

Source: own elaboration based on the results of STEEP analysis. 
requires exceptionally advanced technological solutions and complex algorithms capable of handling a complex system of human behavior.
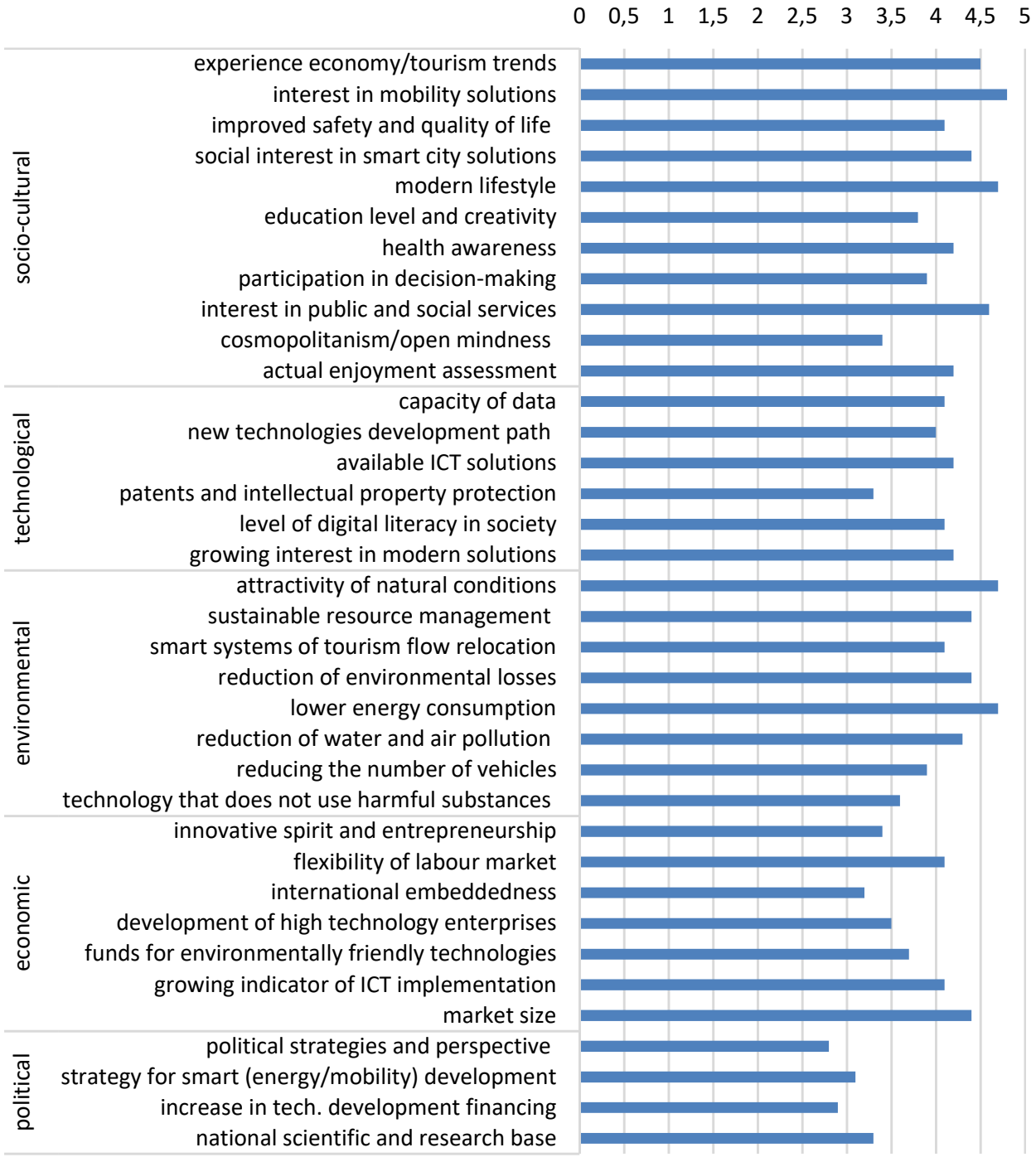

Figure 1. Opportunities of the implementation of smart tourism system in Poland

Source: own elaboration based on the results of STEEP analysis.

Interviewees also noticed a certain area of potential threats and adverse changes in the natural environment as a result of using STD solutions. In particular, representatives of national parks paid attention to this, fearing the installation of new devices necessary for data acquisition (beacons, Wi-Fi routers). Undoubtedly, new devices mean environmental costs associated with their production and operation (energy consumption). 


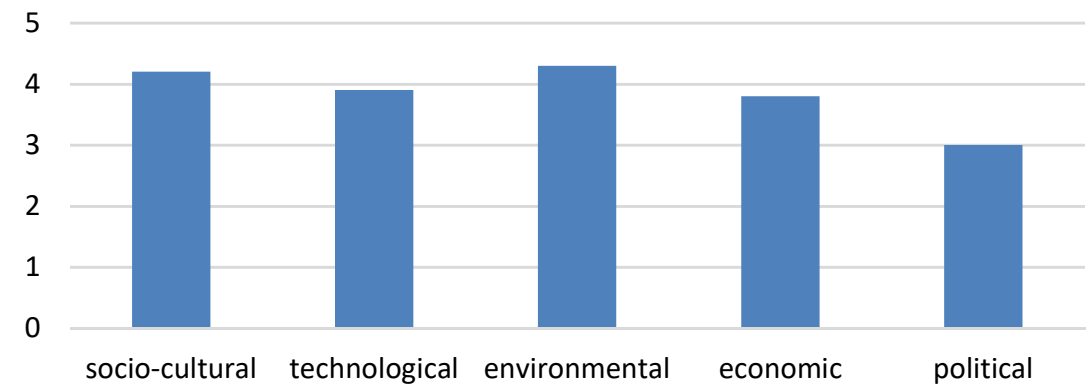

Figure 2. Key categories of opportunities of the implementation of smart tourism system Source: own elaboration based on the results of STEEP analysis.

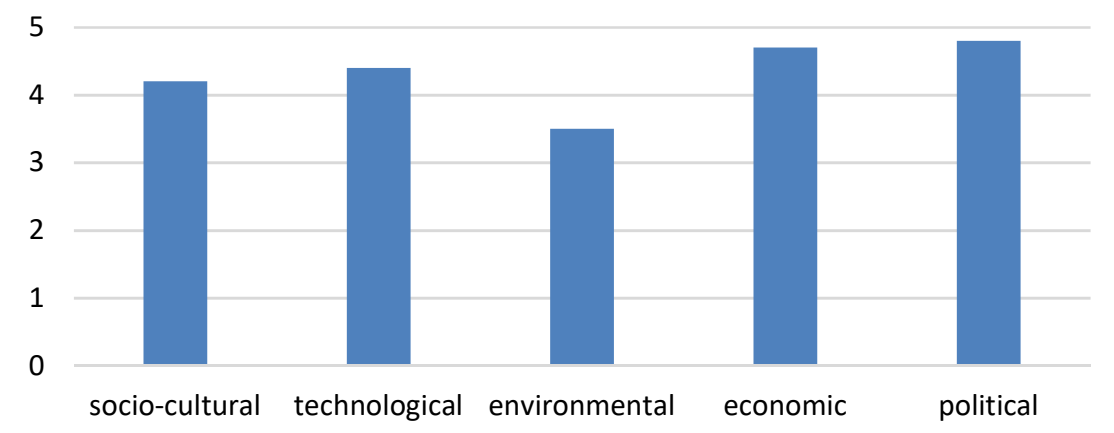

Figure 3. Key categories of threats to the implementation of smart tourism system Source: own elaboration based on the results of STEEP analysis.

The most desirable solution, suggested by the interviewees, would be cooperation with telecommunications operators in the scope of analyzing the whereabouts of users of a given network and their mobility route (GPS signal). Nowadays, femtocells enable the location of mobile phone users, so one can visualize and interpret traffic within the city/region. These data should be combined with data from other sources (hotel reservation systems, ticketing tourism attractions, tourists discussions on social media platforms etc.). Wireless Internet in public transport, tourist attractions, galleries etc. is an additional source of data, which should supply the mobile application informing, e.g. about the location of the nearest points of interests, the best available configuration of transport connections or available parking space (with the possibility of paying a fee).

Due to the negative aspects of mass tourism dynamic development, sustainable transport is one of the most important elements constituting the STD. Even small agglomerations face many problems that did not seem so large a few decades ago. Neglects in the quality and availability of public transport services in the small urban centers in Poland have strongly influenced the mobility behavior of residents and tourists. However, this can be seen as an opportunity: the creation of smart mobility frameworks should at the same time assume appropriate technical and digital infrastructure as well as simultaneous actions to change the communication behavior of residents and tourists. 
$\begin{array}{lllllllllll}0 & 0,5 & 1 & 1,5 & 2 & 2,5 & 3 & 3,5 & 4 & 4,5 & 5\end{array}$

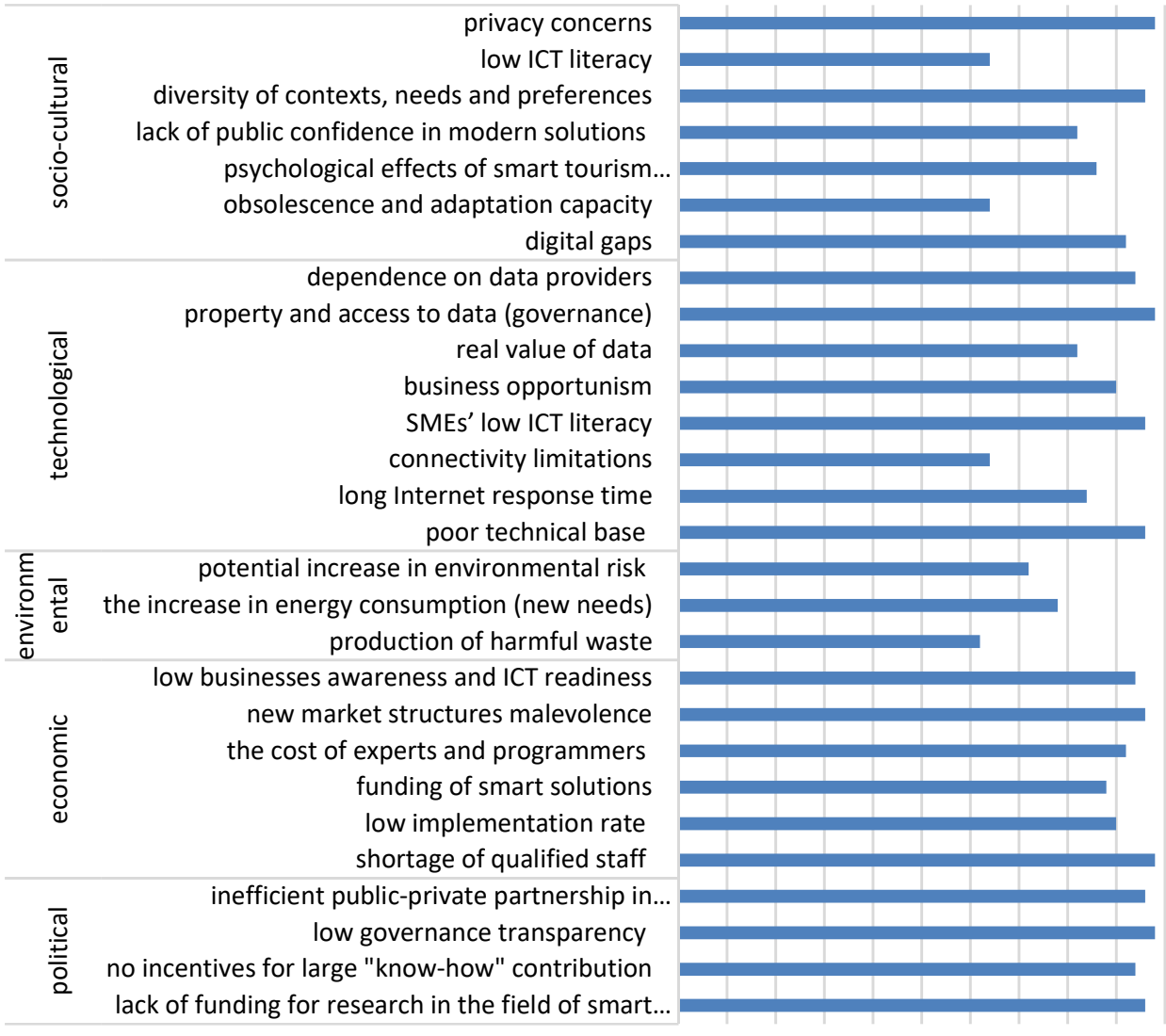

Figure 4. Threats to the implementation of smart tourism system in Poland Source: own elaboration based on the results of STEEP analysis.

The combined results of the literature review and the discussion with panel participants enabled the development of a complex diagram (see Fig. 5) of connections between the elements of the big data system (including all the data available within the digital tourism environment) and smart tourism goals (taking into account wellbeing of the local community, tourists' experience as well as elementary breakdowns regarding business efficiency economic and sustainable development).

The use of digital technologies and their combination with effective organizational models can promote cooperation, knowledge sharing and diffusion of innovation, and as a result provide visitors with innovative integrated tourist-oriented services, highly personalized, which is a source of unique experience and determines the ability of a given tourist region to achieve competitive advantage. At the same time, modern automated methods would allow the better understanding of visitors' desires and behavior, using huge amounts of data made available through the intensive use of online environments and new technological models of effective tools to achieve their goals (AR, robotics, loT, blockchain applications, etc.). 


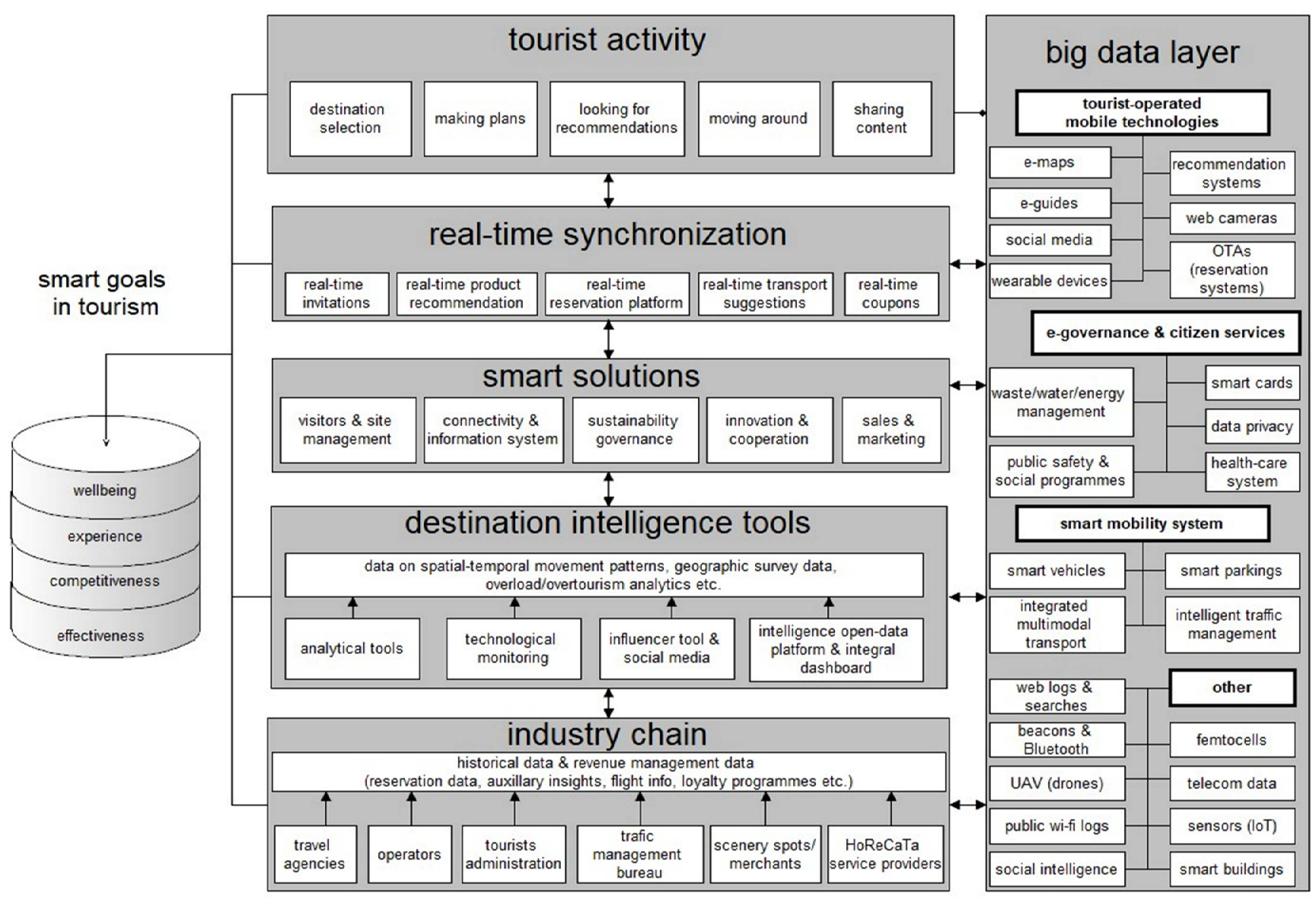

Figure 4. Threats to the implementation of smart tourism system in Poland

Source: own elaboration based on the results of STEEP analysis. 


\section{DISCUSSION AND IMPLICATION FOR FUTURE RESEARCH}

Similarities between the results of this study and the results of previous studies could clearly be identified. In smart tourism, business builds on an extensive "infostructure" and the big data however smart service ecosystems require new alliances and new value chains/networks to share risk and circulate knowledge (Anttiroiko et al., 2014; Gretzel et al., 2015; Tachizawa et al., 2015). There is great competitive pressure to be cost-effective and innovative in (re)configuring services. The resulting smart ecosystems are complex with high transaction costs that probably favour informal governance. The necessary creative mutuality and cooperation in these systems might be more difficult to manage than traditional competitive rivalry. On the other hand, it might open up structural holes that can be exploited by businesses.

Intensive use of data is the most important element connecting modern technological solutions, all the more so because nowadays data can be available in huge quantities because they are generated by the widespread use of online applications. They include not only software available to tourism enterprises (e.g. databases, internet traffic statistics) and tourists (e.g. mobile applications, wearable technologies), but also Internet of Things, where every object equipped with a sensor and capable of connecting with the so-called cloud, can be used as a source of invaluable data for analyzing tourist flows, and the way tourists use the region's resources (e.g. energy, water, climate, cultural, etc.). However, technological foundations will not bring the expected economic and social effects without a thorough review of operational and organizational processes at the level of enterprises as well as ways of managing the tourist region.

Interviewees (representing both, the Polish tourism industry and the new technologies industry) are moderately skeptical about the prospects for the development of smart tourism in Poland. Their fears relate not only to economic and political issues (including the low involvement of the government and local governments in financing and supporting smart projects), but also to socio-cultural challenges, in particular the digital gap that characterizes Polish society and Polish small and medium entrepreneurs, incapable to face innovative business models. The greatest opportunities for the development of smart tourism should be seen in the changing consumption patterns, increasingly sophisticated expectations of tourists in terms of travel experiences offered to them, and - first of all the growing amounts of big data, representing huge capital and real market value, which cannot be left aside in the conditions of growing competition on the tourism market.

All the concept relies on an abundance of free information; on an access to open technological platforms and on the assumption that data is willingly shared by consumers. As a result, smart tourism infostructure can lead to new information asymmetries that can be commercially exploited as economic power is derived from control over information flows (Tachizawa et al., 2015). Businesses seeking to operate within smart tourism environments have to consider "value-in-use" (Bick et al., 2012). Privacy is therefore an obvious concern in the context of smart tourism. Especially location-based services, while extremely useful for tourists, also make consumers vulnerable. 


\section{CONCLUSIONS}

Realization of smart tourism and smart tourists clearly depends on the ability to collect large amounts of data, requisite computing power, smart use of algorithms, and making insights available to specific tourists in real time. The massive scale innovation in deriving insights from big data is crucial in success of smart tourism. STD definitely provides context aware real-time insights but at the same time it creates challenges in privacy concerns, right to co-created value, socio-psychological implications of ubiquitous connectivity, universal and neutral access to technology, evolving suitable business models, role of governments vis-a-vis private players with conflicting objectives. Smart tourism - still in infancy - offers great promise in near and distant future.

Big data has overwhelmed the imaginations of researchers and business practitioners. It is mindlessly captured and information management costs are rarely calculated. Smart tourism concept implementations should force local governments/businesses to carefully think about what data they have and in what way it could be made useful. A major area of research necessary in the context of smart tourism is information management and privacy (ensuring safety and security in open and ubiquitous info-structures).

\section{REFERENCES}

Ahas, R., Aasa, A., Roose, A., Mark, U., \& Silm, S. (2008). Evaluating passive mobile positioning data for tourism surveys: An Estonian case study. Tourism Management, 29(3), 469-486.

Anttiroiko, A. V., Valkama, P., \& Bailey, S. J. (2014). Smart cities in the new service economy: building platforms for smart services. Al and Society, 29(3), 323-334.

Artola, C., Pinto, F., \& Pedraza, P. D. (2015). Can internet searches forecast tourism inflows? International Journal of Manpower, 36(1), 103-116.

Baggio, R.,\& Del Chiappa, G. (2014). Real and virtual relationships in tourism digital ecosystems. Information Technology and Tourism, 14(1), 3-19.

Bick, M., Bruns, K., Sievert, J., \& Jacob, F. (2012). Value-in-use of mobile technologies. In A. Back, M. Bick,M.Breunig, K.Pousttchi, \&F. Thiesse, (Eds.) MMS 2012: Mobile und ubiquitäreinformationssysteme (pp. 56-67). KöllenDruck \& Verlag.

Bollier, D., \& Firestone, C. (2010). The promise and peril of big data. Aspen.

Cooper, M., \& Macneil, N. J. (2005). Virtual reality mapping: IT tools for the divide between knowledge and action in tourism. Tourism Recreation Research, 30(3), 61-68.

Femenia-Serra F., \& Perea-Medina, M. J. (2016)., Analysis of Three Spanish Potential Smart Tourism Destinations. Paper presented at the 6th International Conference On Tourism (ICOT). Naples.

Frederiksen, L. (2012). Big data. Public Services Quarterly, 8(4), 345-349.

Gavalas, D., \& Kenteris, M.(2011). A pervasive web-based recommendation system for mobile tourist guides. Personal and Ubiquitous Computing 15(7), 759-70.

Girardin, F., Fiore, F. D., Ratti, C., \& Blat, J. (2008). Leveraging explicitly disclosed location information to understand tourist dynamics: A case study. Journal of Location Based Services, 2(1), 41-56.

González-Reverté, F. (2019). Building Sustainable Smart Destinations: An Approach Based on the Development of Spanish Smart Tourism Plans.Sustainability, 11(23), 1-24.

Govers, R., Go, F. M., \& Kumar, K. (2007). Promoting tourism destination image. Journal of Travel Research, 46(1), 15-23. 
Gretzel, U., Sigala, M., Xiang, Z., \& Koo, C. (2015). Smart tourism: foundations and developments. Electronic Markets, 25(3), 179-188.

Guttentag, D. A. (2010). Virtual reality: Applications and implications for tourism. Tourism Management, 31(5), 637-651.

Hawelka, B., Sitko, I., Beinat, E., Sobolevsky, S., Kazakopoulos, P., \& Ratti, C. (2014). Geo-located Twitter as proxy for global mobility patterns. Cartography and Geographic Information Science, 41(3), 260-271.

Hendrik, H., \& Perdana, D. H. F. (2014). Trip guidance: A linked data based mobile tourists guide. Advanced Science Letters, 20(1), 75-79.

Irudeen, R., \& Samaraweera, S. (2013). Big data solution for Sri Lankan development: A case study from travel and tourism. Paper presented at the 2013 International Conference on Advances in ICT for Emerging Regions, ICTer 2, Colombo.

Jeng, J., \& Fesenmaier, D. R. (2002). Conceptualizing the travel decision-making hierarchy: A review of recent developments. Tourism Analysis, 7(1), 15-32.

Kachniewska, M. (2014). Tourism value added creation through a user-centric context-aware digital system.University of Szczecin Scientific Journal, 836, Economic Problems of Tourism, 4 (28), 103-118.

Ka'da'r, B. (2014). Measuring tourist activities in cities using geotagged photography. Tourism Geographies, 16(1), 88-104.

Kim, J. J., \& Fesenmaier, D. R. (2015). Designing tourism places: Understanding the tourism experience through our senses. In 2015 Tourism Travel and Research Association International Conference Proceedings. Portland, Oregon.

Komninos, N. (2008). Intelligent Cities and Globalisationof Innovation Networks. Routledge.

Kurilovas, E. (2016). Evaluation of quality and personalisation of VR/AR/MR learning systems. Behaviour\& Information Technology, 35(11), 998-1007.

Lamsfus, C., Wang, D., Alzua-Sorzabal, A., \& Xiang, Z. (2014). Going mobile: Defining context for onthe-go travelers. Journal of Travel Research, 54(6), 691-701.

Li, D., \& Yang, Y. (2020) GIS Monitoring of Traveler Flows Based on Big Data.In J.Neidhardt, W.Wörndl (Eds.), Information and Communication Technologies in Tourism 2020. United Kingdom, January 08-10, 2020. Retrieved from: https://enter2020.ifitt.org/

Lopez de Avila, A. (2015). Smart Destinations: XXI Century Tourism. Presented at the ENTER2015 Conference on Information and Communication Technologies in Tourism, Lugano, Switzerland, February 4-6, 2015.

Manyika, J., Chui, M., Brown, B.,Bughin, J., Dobbs, R., Roxburgh, Ch., \& Hung Byers,A. (2011).Big Data: The Next Frontier for Innovation. McKinsey Global Institute.

Mariani, M., Baggio, R., Fuchs, M., \&Höpken, W. (2018). Business Intelligence and Big Data in Hospitality and Tourism: A Systematic Literature Review. International Journal of Contemporary Hospitality Management, 30(12), 3514-3554.

Masseno, M., \&Santos, Ch. (2018) Between Footprints: Balancing Environmental Sustainability and Privacy in Smart Tourism Destinations. United World Law Journal, 1(II), 96-11.

Meeker, W. Q., \& Hong, Y. (2014). Reliability meets big data: Opportunities and challenges. Quality Engineering, 26(1), 102-116.

Olsen, M., \& Connolly, D. (2000). Experience-based Travel: How Technology Is Changing the Hospitality Industry. Cornell Hospitality Quarterly, 41(1), 30-40. 
Scharl, A., Lalicic, L., \&Önder, I. (2020). Tourism Intelligence and Visual Media Analytics for Destination Management Organizations. In J.Neidhardt, W. Wörndl (Eds.), Information and Communication Technologies in Tourism 2020. Proceedings of the International Conference in Surrey, United Kingdom, January 08-10, 2020.

Shoval, N., Isaacson, M., \& Chhetri, P. (2013). GPS, Smartphones, and the future of tourism research. In A. A. Lew, C. M. Hall, \& A. M. Williams (Eds.), The Wiley Blackwell companion to tourism (251261). Blackwell.

Song, H., Liu, H. (2017). Predicting Tourist Demand Using Big Data. InZ. Xiang, D. R. Fesenmaier (Eds.) Analytics in Smart Tourism Design. Springer.

Swan, M. (2013). The quantified self: Fundamental disruption in big data science. Big Data, 1(2), 85-99.

Tachizawa, E. M., Alvarez-Gil, M. J., \& Montes-Sancho, M. J. (2015). How smart cities will change supply chain management. Supply Chain Management, 20(3), 237-248.

Townsend, P. (2017).The Dark Side of Technology. Oxford University Press.

Vasavada, M., \&Padhiyar, Y. J. (2016). "Smart Tourism": Growth for Tomorrow.Journal for Research, 01(12).

Versichele, M., Neutens, T., Delafontaine, M., \& Van de Weghe, N. (2012). The use of Bluetooth for analyzing spatiotemporal dynamics of human movement at mass events: A case study of the Ghent Festivities. Applied Geography, 32(2), 208-220.

Vu, H. Q., Li, G., Law, R., \& Ye, B. H. (2015). Exploring the travel behaviors of inbound tourists to Hong Kong using geotagged photos. Tourism Management, 46, 222-232.

Yang, X., Pan, B., Evans, J. A., \&Lv, B. (2015). Forecasting Chinese tourist volume with search engine data. Tourism Management, 46, 386-397.

\section{Author}

\section{Magdalena Kachniewska}

$\mathrm{PhD}$ in tourism economics. Member of Tourism Research Working Group and Scientific Council of e-TravelForum. Chairperson in "New.Tech.New.Travel" contest. Strategic Management and Social Marketing expert specialising in ICT applications in tourism and hospitality.

Correspondence to: Prof. Magdalena Kachniewska, PhD, Warsaw School of Economics, Department of International Management, Al. Niepodleglosci 162, 02-554 Warsaw, Poland, e-mail: mkachni@sgh.waw.pl

ORCID (1) http://orcid.org/0000-0003-3163-0868

\section{Copyright and License}

This article is published under the terms of the Creative Commons Attribution - NoDerivs (CC BY-ND 4.0) License

http://creativecommons.org/licenses/by-nd/4.0/

Published by Cracow University of Economics - Krakow, Poland

Ministry of Science and Higher Education Republic of Poland
The journal is co-financed in the years 2019-2020 by the Ministry of Science and Higher Education of the Republic of Poland in the framework of ministerial programme "Support for Scientific Journals" (WCN) on the basis of contract no. 238/WCN/2019/1 concluded on 15 August 2019. 